J. AMER. SOC. HORT. SCI. 115(3):440-443. 1990.

\title{
Storage Characteristics of Small Watermelon Cultivars
}

\author{
L.A. Risse \\ U.S. Department of Agriculture, Agricultural Research Service, Horticultural Research Laboratory, \\ 2120 Camden Road, Orlando, FL 32803
}

J.K. Brecht, S.A. Sargent, and S.J. Locascio

Vegetable Crops Department, University of Florida, Gainesville, FL 32611

J.M. Crall and G.W. Elmstrom

Agricultural Research and Education Center, Leesburg, FL 32748

D.N. Maynard

Gulf Coast Research and Education Center, Bradenton, FL 32508

Additional index words. chilling injury, decay, firmness, total soluble solids, conditioning, flesh color

\begin{abstract}
Two newly released cultivars of small watermelons [Citrullus lunatus (Thumb.) Matsum and Naki], 'Mickylee' and 'Minilee', plus two other cultivars, Baby Fun and Sugar Baby, were stored at various temperatures from 1 to $21 \mathrm{C}$ for up to 4 weeks plus 1 week at $21 \mathrm{C}$ over two seasons. All cultivars were susceptible to chilling injury (CI) when stored below 7C; however, 'Minilee' was less susceptible than the other cultivars tested. Chilling injury increased with storage length. Conditioning at $26 \mathrm{C}$ for 3 days before storage at $1 \mathrm{C}$ reduced $\mathrm{CI}$ and increased the percentage of marketable watermelons after storage. Decay percentage increased with storage time and was highest on fruit held at $1 \mathrm{C}$ where CI led to decay. The flesh of 'Mickylee' and 'Minilee' was firmer than that of the other cultivars tested and 'Mickylee' and Minilee' retained their firmness better during storage. Total soluble solids concentration decreased with increased storage temperature. 'Minilee' watermelons were superior to the other three cultivars in postharvest storage potential and exhibited the least CI and decay.
\end{abstract}

Watermelon production in the United States has traditionally centered around production of large-fruited types. United States per-capita consumption has dropped $30 \%$, from $8.2 \mathrm{~kg}$ during the $1950 \mathrm{~s}$ to $5.9 \mathrm{~kg}$ during the $1980 \mathrm{~s}$. The drop in watermelon consumption has been attributed to smaller families, inconvenience in handling large watermelons, and, if sliced at retail, higher per-unit prices. Small watermelon cultivars, sometimes called icebox watermelons; have been available for many years. Their yield and quality have not been as good as that of the large melons. Two recently released cultivars, Minilee and Mickylee, developed by Crall (1986), have acceptable yields and excellent eating quality. These two cultivars also are resistant to anthracnose and fusarium wilt. The flesh of these fruit is very crisp and total soluble solids (TSS) range from $10 \%$ to $12 \%$ at maturity. In recent years, imports of watermelons of 'Mickylee' and 'Minilee' from Central and South America and the Caribbean Islands have been increasing.

Watermelons generally are not refrigerated when shipped domestically. However, refrigerated storage and transit may be used to extend the shelf life during export shipment. The recommended range is 10 to $15 \mathrm{C}$ (Hardenburg et al., 1986). At lower temperatures, fruit are susceptible to CI and decay (Dow et al., 1979) and loss of color (Showalter, 1960). At higher temperatures, fruit are subject to decay (Leupeschen, 1961) and sugar loss (Chisholm and Picha, 1986). Prestorage conditioning at $26 \mathrm{C}$ for 4 days reduces development of $\mathrm{CI}$ and increases the percentage of marketable fruit following storage (Picha, 1986).

The objective of this study was to determine the storage quality potential of small watermelon cultivars in the range of 1 to $21 \mathrm{c}$.

Received for publication 20 Apr. 1989. The cost of publishing this paper was defrayed in part by the payment of page charges. Under postal regulations, this paper therefore must be hereby marked advertisement solely to indicate this fact.

\section{Materials and Methods}

Three independent storage tests were conducted; two at Orlando and one at Gainesville, Fla. The fruit for the Orlando tests were harvested from plantings at the Univ. of Florida's Agricultural Research Centers at Bradenton or Leesburg during 1987 and 1988. Three harvests were made for each test in 1987 and 1988 with 'Baby Fun', 'Mickylee', and 'Minilee'. One harvest at Gainesville was made from plantings at Univ. of Florida's Horticultural Unit plots with 'Baby Fun', 'Mickylee', 'Minilee', and 'Sugar Baby'. Harvested fruit for the Gainesville test were rinsed with tap water to remove field debris and dipped for 1 min in a $0.5 \%$ solution of sodium-o-phenyl-phenate (SOPP) (FMC Freshguard, Lakeland, Fla.). Fruit for the Orlando tests were not treated.

Five fruit of each cultivar were stored at 1, 7, 13, or 21C for $1,2,3$, or 4 weeks plus 1 additional week at $21 \mathrm{C}$ for the tests in 1987 at Orlando. For the 1988 Orlando test, five fruit of each cultivar were stored at $1,7,13$, or $21 \mathrm{C}$ for 3 weeks plus 1 additional week at $21 \mathrm{C}$. Two additional treatments were added to this test: conditioning at $26 \mathrm{C}$ for 3 days at high $(90 \% \pm 5 \%)$ or low $(60 \% \pm 5 \%) \mathrm{RH}$ before storage at $1 \mathrm{C}$. Five fruit of each cultivar for the Gainesville test were stored at 5, 10, 15, or 20C for 2 or 4 weeks plus 4 additional days at 20C. Storage rooms in the Orlando tests were maintained at the desired temperature $\pm 0.5 \mathrm{C}$ and $\mathrm{RH}$ of $85 \% \pm 5 \%$; those in the Gainesville test were maintained at the desired temperature $+0.5 \mathrm{C}$. Relative humidity was $90 \% \pm 5 \%$ in the 5,10 , and $15 \mathrm{C}$ rooms and $70 \%$ $\pm 5 \%$ in the $20 \mathrm{C}$ room. All melons were in storage within 4 to $8 \mathrm{hr}$ after harvest.

At Orlando, the fruit were scored at each evaluation for CI ( $1=$ none, $2=<10 \%$ of surface area, $3=11 \%$ to $25 \%, 4$ $=26 \%$ to $50 \%$, and $5=>50 \%$ ), stem condition (sound or not), and decay. CI of watermelon surface is indicated by brownish, water-soaked areas. Marketable fruit were considered to be without decay and not overripe. The fruit were then cut 
Table 1. Chilling injury rating and percentage of marketable watermelons stored for $1,2,3$, or 4 weeks at $1,7,13$, or $21 \mathrm{C}^{\mathrm{z}}$ plus 1 additional week at $21 \mathrm{C}$ (three tests, 1987, Orlando).

\begin{tabular}{|c|c|c|c|c|c|c|c|c|c|}
\hline \multicolumn{2}{|c|}{ Storage } & \multicolumn{3}{|c|}{ Chilling injury (rating) ${ }^{x}$} & \multirow[b]{2}{*}{$\overline{\mathbf{x}}$} & \multicolumn{3}{|c|}{ Marketabley $(\%)$} & \multirow[b]{2}{*}{$\overline{\mathrm{x}}$} \\
\hline $\begin{array}{c}\text { Temperature } \\
\text { ( } \mathrm{C} \text { ) }\end{array}$ & $\begin{array}{l}\text { Time } \\
\text { (wk) }\end{array}$ & Minilee & Mickylee & $\begin{array}{c}\text { Baby } \\
\text { Fun }\end{array}$ & & Minilee & Mickylee & $\begin{array}{l}\text { Baby } \\
\text { Fun }\end{array}$ & \\
\hline 1 & 1 & 1.0 & 1.5 & 1.3 & $\cdots$ & 100 & 100 & 100 & -.. \\
\hline & 2 & 1.4 & 2.3 & 1.8 & -.- & 75 & 67 & 50 & -.. \\
\hline & 3 & 2.3 & 3.8 & 4.0 & --- & 58 & 58 & 60 & $\ldots$ \\
\hline & 4 & 2.5 & 3.7 & 4.0 & 2.4 & 17 & 25 & 38 & 61 \\
\hline 7 & 1 & 1.0 & 1.0 & 1.0 & -- & 100 & 100 & 100 & -- \\
\hline & 2 & 1.2 & 1.3 & 1.1 & $-\cdots$ & 92 & 83 & 100 & $\ldots$ \\
\hline & 3 & 1.5 & 1.8 & 1.8 & $\cdots$ & 50 & 83 & 50 & ..- \\
\hline & 4 & 2.0 & 2.0 & 2.3 & 1.5 & 25 & 25 & 30 & 71 \\
\hline 13 & 1 & 1.0 & 1.0 & 1.0 &.- & 92 & 100 & 100 & ... \\
\hline & 2 & 1.0 & 1.0 & 1.0 & -.- & 83 & 92 & 40 & ... \\
\hline . & 3 & 1.0 & 1.0 & 1.0 & -- & 92 & 75 & 60 & -.. \\
\hline & 4 & 1.0 & 1.0 & 1.0 & 1.0 & 67 & 58 & 0 & 71 \\
\hline 21 & 1 & 1.0 & 1.0 & 1.0 &.- & 100 & 100 & 100 & -.. \\
\hline & 2 & 1.0 & 1.0 & 1.0 & -.. & 100 & 100 & 100 & $\ldots$ \\
\hline & 3 & 1.0 & 1.0 & 1.0 & -.. & 92 & 92 & 90 & -.. \\
\hline & 4 & 1.0 & 1.0 & 1.0 & 1.0 & 83 & 92 & 60 & 93 \\
\hline $\bar{x}^{w}$ & $\cdots$ & $1.3 \mathrm{~b}$ & $1.6 \mathrm{a}$ & $1.6 \mathrm{a}$ & $\cdots$ & $76 a$ & $78 \mathrm{a}$ & $67 \mathrm{~b}$ & -- \\
\hline
\end{tabular}

${ }^{\mathrm{z}}$ All storage rooms maintained at $\pm 0.5 \mathrm{C}$ and $85 \% \pm 5 \% \mathrm{RH}$.

${ }^{\mathrm{y}}$ Melons ripe and not decayed.

${ }^{x}$ Chilling injury ratings: $1=$ none, $2=<10 \%$ of surface area, $3=11 \%$ to $25 \%, 4=26 \%$ to $50 \%$, and $5=>50 \%$.

${ }^{\mathrm{w}}$ Means separation in row by Duncan's multiple range test, $P=0.05$.

Table 2. Quality characteristics of three small watermelon cultivars stored at $1,7,13$, or $21 \mathrm{C}^{\mathrm{z}}$ for 4 weeks plus 1 additional week at 21C (three tests, 1987, Orlando).

\begin{tabular}{|c|c|c|c|}
\hline Treatment & Firmness & $\begin{array}{c}\text { Total soluble } \\
\text { solids } \\
\text { (\%) }\end{array}$ & $\begin{array}{c}\text { Marketable fruity } \\
(\%)\end{array}$ \\
\hline \multicolumn{4}{|c|}{ Cultivar averaged over temperatures ${ }^{x}$} \\
\hline $\begin{array}{l}\text { Mickylee } \\
\text { Baby Fun } \\
\text { Minilee }\end{array}$ & $\begin{array}{l}16.7 \mathrm{a} \\
11.1 \mathrm{~b} \\
15.5 \mathrm{a}\end{array}$ & $\begin{array}{l}10.2 \mathrm{~b} \\
11.1 \mathrm{a} \\
11.0 \mathrm{a}\end{array}$ & $\begin{array}{l}58 \mathrm{a} \\
30 \mathrm{c} \\
48 \mathrm{~b}\end{array}$ \\
\hline \multicolumn{4}{|c|}{ Temperature $\left({ }^{\circ} \mathrm{C}\right)$ averaged over cultivars } \\
\hline 1 & 14.1 & 12.3 & 24 \\
\hline 7 & 14.4 & 10.7 & 27 \\
\hline 13 & 16.2 & 10.0 & 53 \\
\hline 21 & 13.7 & 9.8 & 78 \\
\hline
\end{tabular}

${ }^{\mathrm{z}}$ Storage rooms maintained at $\pm 0.5 \mathrm{C}$ and $85 \% \pm 5 \% \mathrm{RH}$.

${ }^{\mathrm{y}}$ Melons ripe and not decayed.

${ }^{\mathrm{x}}$ Means separation in columns by Duncan's multiple range test, $P=$ 0.05 .

in half before being evaluated for ripeness stage at Gainesville ( 1 = unripe, 2 = ripe, $3=$ overripe). Rind thickness was measured at three equally spaced locations around the circumference of the fruit. Color of a section of flesh at the center or heart area was measured with a color difference meter (Model D25-9, Hunterlab, Reston, Va.) signal processor with an optical sensor (model D25-L).

A section of flesh $(3 \times 8 \mathrm{~cm}$ and $\approx 2 \mathrm{~cm}$ deep $)$ in the Orlando tests was cut from the central area of the fruit and a food-testing system (Model 1132, Instron, Canton, Mass.) was used to measure firmness. Firmness was measured by applying a load cell calibrated to a range of $0-10 \mathrm{~kg}$ at a constant speed of $5 \mathrm{~cm} \cdot \mathrm{min}^{-1}$ equipped with a round-ended probe $(1.1 \mathrm{~cm}$ in diameter). The amount of force required to enter the fruit surface to a depth of $5 \mathrm{~mm}$ was recorded. Three readings were taken on each melon.
Two tissue sections $(3 \times 3 \times 10 \mathrm{~cm})$ from opposite fruit halves were used to measure flesh firmness in the Gainesville test. The firmness was measured with a firmness testing device (Chatillon Model HTCM, John Chatillon and Sons, New York) with a crosshead speed of $20 \mathrm{~cm} \cdot \mathrm{min}^{-1}$ and equipped with a roundended probe $(1.1 \mathrm{~cm}$ in diameter).

The TSS content of the juice was determined by homogenizing in a blender the two tissue sections used for flesh firmness, centrifuging an aliquot of the resultant slurry at $12,000 \times g$, and measuring the supernatant with an Abbé refractometer in the Gainesville test. TSS was determined by squeezing juice from the heart section, previously used for color and firmness measurements, directly onto a hand-held refractometer in the Orlando tests.

All data were statistically analyzed using an analysis of variance, and Duncan's multiple range test was used to separate means.

\section{Results}

All three cultivars in the 1987 tests at Orlando were susceptible to $\mathrm{CI}$ at 1 at 7C. 'Minilee' was the least-susceptible cultivar (Table 1). CI was more severe at 1 than $7 \mathrm{C}$ and the severity of $\mathrm{CI}$ increased with increased storage time. The percentage of marketable watermelons was highest at $21 \mathrm{C}$ and lowest at $1 \mathrm{C}$ (Table 1). At 1 and $7 \mathrm{C}$, most of the decay originated on the sites of $\mathrm{CI}$, and at 13 and $21 \mathrm{C}$, most decay originated from the stem end. Decay increased with storage time. 'Mickylee' and 'Minilee' fruit were less susceptible to decay than 'Baby Fun'. 'Mickylee' and 'Minilee' fruit were firmer than 'Baby Fun' fruit during storage (Table 2). TSS values were higher for 'Baby Fun' and 'Minilee' than for 'Mickylee' fruit. TSS decreased with increased storage temperature. The percentage of marketable watermelons was highest for 'Mickylee' fruit, followed by 'Minilee' and 'Baby Fun' fruit, during this extended storage period. Storage at $21 \mathrm{C}$ resulted in the highest percentage of 
Table 3. Quality characteristics of three small watermelon cultivars stored at $1 \mathrm{C}$ (with and without conditioning), 7, 13, or $21 \mathrm{C}$ for 3 weeks plus 1 additional week at $21 \mathrm{C}$ (three tests, 1988, Orlando) .

\begin{tabular}{|c|c|c|c|c|c|c|c|}
\hline Treatment & $\begin{array}{l}\text { Chilling } \\
\text { injury } \\
\text { (rating) }\end{array}$ & Firmness & $\begin{array}{c}\text { Total soluble } \\
\text { solids } \\
(\%)\end{array}$ & $\begin{array}{l}\text { Overripe } \\
(\%)\end{array}$ & $\begin{array}{c}\text { Sound } \\
\text { stems } \\
(\%)\end{array}$ & $\begin{array}{l}\text { Decay } \\
(\%)\end{array}$ & $\begin{array}{c}\text { Marketabley } \\
(\%)\end{array}$ \\
\hline \multicolumn{8}{|c|}{ Cultivar averaged over temperature and conditioningx } \\
\hline $\begin{array}{l}\text { Mickylee } \\
\text { Baby Fun } \\
\text { Minilee }\end{array}$ & $\begin{array}{l}2.2 \mathrm{~b} \\
2.4 \mathrm{a} \\
1.8 \mathrm{c}\end{array}$ & $\begin{array}{r}15.7 \mathrm{a} \\
7.8 \mathrm{~b} \\
14.7 \mathrm{a}\end{array}$ & $\begin{array}{l}11.1 \mathrm{a} \\
10.8 \mathrm{~b} \\
10.6 \mathrm{~b}\end{array}$ & $\begin{array}{r}3 b \\
19 a \\
8 b\end{array}$ & $\begin{array}{l}49 \mathrm{~b} \\
51 \mathrm{~b} \\
58 \mathrm{a}\end{array}$ & $\begin{array}{r}10 \mathrm{~b} \\
26 \mathrm{a} \\
2 \mathrm{~b}\end{array}$ & $\begin{array}{l}87 \mathrm{a} \\
55 \mathrm{~b} \\
90 \mathrm{a}\end{array}$ \\
\hline \multicolumn{8}{|c|}{ Temperature averaged over cultivar } \\
\hline $\begin{array}{l}1 \mathrm{C} \\
\text { Cond HRH }+1 \mathrm{1C} \\
\text { Cond LRH + } 1 \mathrm{C} \\
7 \mathrm{C} \\
13 \mathrm{C} \\
21 \mathrm{C}\end{array}$ & $\begin{array}{l}3.9 \\
2.5 \\
2.6 \\
1.6 \\
1.0 \\
1.0\end{array}$ & $\begin{array}{l}14.7 \\
12.7 \\
11.8 \\
12.7 \\
12.7 \\
11.8\end{array}$ & $\begin{array}{l}11.1 \\
11.2 \\
11.3 \\
11.3 \\
10.9 \\
10.6\end{array}$ & $\begin{array}{r}0 \\
2 \\
5 \\
9 \\
16 \\
23\end{array}$ & $\begin{array}{l}23 \\
67 \\
72 \\
42 \\
23 \\
88\end{array}$ & $\begin{array}{r}52 \\
16 \\
9 \\
19 \\
9 \\
2\end{array}$ & $\begin{array}{l}48 \\
82 \\
86 \\
72 \\
75 \\
75\end{array}$ \\
\hline
\end{tabular}

${ }^{\mathrm{z}}$ Conditioning 3 days at $26 \mathrm{C}$ at either high $(90 \% \pm 5 \%$; HRH) or low RH(60\% $\pm 5 \%$; LRH). All other storage rooms maintained at $\pm 0.5 \mathrm{C}$ and $85 \% \pm 5 \% \mathrm{RH}$.

${ }^{\mathrm{y}}$ Melons ripe and not decayed.

${ }^{\mathrm{x}}$ Means separation in columns by Duncan's multiple range test, $P=0.05$.

Table 4. Quality characteristics of four small watermelon cultivars stored at 5, 10, 15, or 20C for 4 weeks (one test, 1987, Gainesville) ${ }^{z, y}$.

\begin{tabular}{|c|c|c|c|c|c|c|}
\hline Cultivar & $\begin{array}{c}\text { Ripeness } \\
\text { (rating) }\end{array}$ & $\begin{array}{l}\text { Color } \\
\left({ }^{\prime} a \text { ') }\right.\end{array}$ & Firmness & $\begin{array}{l}\text { Rind } \\
\text { thickness } \\
\text { (mm) }\end{array}$ & $\begin{array}{c}\text { Total soluble } \\
\text { solids } \\
(\%)\end{array}$ & $\begin{array}{c}\text { Decay } \\
(\%)\end{array}$ \\
\hline $\begin{array}{l}\text { Sugar Baby } \\
\text { Baby Fun } \\
\text { Minilee } \\
\text { Mickylee } \\
\text { Avg. }\end{array}$ & $\begin{array}{l}1.2 \mathrm{a} \\
1.6 \mathrm{a} \\
2.0 \mathrm{a} \\
1.6 \mathrm{a} \\
1.6\end{array}$ & $\begin{array}{l}18.2 \mathrm{~b} \\
28.9 \mathrm{a} \\
34.3 \mathrm{a} \\
28.7 \mathrm{a} \\
27.5\end{array}$ & $\begin{array}{l}\text { At harvest } \\
18.2 \mathrm{~b} \\
17.3 \mathrm{~b} \\
25.8 \mathrm{a} \\
16.5 \mathrm{~b} \\
19.5\end{array}$ & $\begin{array}{l}12.8 \mathrm{~b} \\
13.3 \mathrm{~b} \\
11.7 \mathrm{~b} \\
15.2 \mathrm{a} \\
13.3\end{array}$ & $\begin{array}{c}7.6 \mathrm{c} \\
10.2 \mathrm{ab} \\
10.6 \mathrm{a} \\
9.3 \mathrm{~b} \\
9.4\end{array}$ & $\cdots$ \\
\hline $\begin{array}{l}\text { Sugar Baby } \\
\text { Baby Fun } \\
\text { Minilee } \\
\text { Mickylee : } \\
\text { Avg. }\end{array}$ & $\begin{array}{l}1.2 \mathrm{~b} \\
1.2 \mathrm{~b} \\
2.2 \mathrm{a} \\
2.2 \mathrm{a} \\
1.7\end{array}$ & $\begin{array}{l}27.7 \mathrm{a} \\
26.8 \mathrm{a} \\
29.8 \mathrm{a} \\
28.1 \mathrm{a} \\
28.1\end{array}$ & $\begin{array}{c}\text { Stored at } 5 C \\
11.1 \mathrm{~b} \\
8.9 \mathrm{~b} \\
12.9 \mathrm{~b} \\
16.0 \mathrm{a} \\
12.2\end{array}$ & $\begin{array}{l}13.1 \mathrm{a} \\
13.4 \mathrm{a} \\
13.7 \mathrm{a} \\
13.6 \mathrm{a} \\
13.5\end{array}$ & $\begin{array}{r}9.7 \mathrm{a} \\
10.2 \mathrm{a} \\
10.1 \cdot \mathrm{a} \\
9.1 \mathrm{a} \\
9.8\end{array}$ & $\begin{array}{c}14 a^{x} \\
17 a \\
14 a \\
25 a \\
17.5\end{array}$ \\
\hline $\begin{array}{l}\text { Sugar Baby } \\
\text { Baby Fun } \\
\text { Minilee } \\
\text { Mickylee } \\
\text { Avg. }\end{array}$ & $\begin{array}{l}3.0 \mathrm{a} \\
2.0 \mathrm{a} \\
2.2 \mathrm{a} \\
2.3 \mathrm{a} \\
2.4\end{array}$ & $\begin{array}{l}28.7 \mathrm{~b} \\
27.8 \mathrm{~b} \\
28.7 \mathrm{~b} \\
34.9 \mathrm{a} \\
30.0\end{array}$ & $\begin{array}{c}\text { Stored at } 10 C \\
8.9 \mathrm{c} \\
16.5 \mathrm{~b} \\
11.1 \mathrm{c} \\
20.5 \mathrm{a} \\
14.3\end{array}$ & $\begin{array}{l}15.0 \mathrm{a} \\
12.9 \mathrm{a} \\
10.6 \mathrm{a} \\
13.4 \mathrm{a} \\
13.0\end{array}$ & $\begin{array}{c}10.7 \mathrm{a} \\
10.8 \mathrm{a} \\
10.5 \mathrm{a} \\
9.3 \mathrm{a} \\
10.3\end{array}$ & $\begin{array}{l}44 \mathrm{~b} \\
39 \mathrm{~b} \\
15 \mathrm{c} \\
70 \mathrm{a} \\
42\end{array}$ \\
\hline $\begin{array}{l}\text { Sugar Baby } \\
\text { Baby Fun } \\
\text { Minilee } \\
\text { Mickylee } \\
\text { Avg. }\end{array}$ & $\begin{array}{l}2.3 \mathrm{a} \\
2.8 \mathrm{a} \\
2.6 \mathrm{a} \\
3.0 \mathrm{a} \\
2.7\end{array}$ & $\begin{array}{l}25.7 \mathrm{c} \\
30.0 \mathrm{a} \\
29.0 \mathrm{~b} \\
32.3 \mathrm{a} \\
29.3\end{array}$ & $\begin{array}{l}\text { Stored at } 15 \mathrm{C} \\
12.5 \mathrm{~b} \\
12.0 \mathrm{~b} \\
10.2 \mathrm{~b} \\
17.8 \mathrm{a} \\
13.1\end{array}$ & $\begin{array}{c}9.5 \mathrm{~b} \\
9.6 \mathrm{~b} \\
11.4 \mathrm{a} \\
11.7 \mathrm{a} \\
10.6\end{array}$ & $\begin{array}{l}10.0 \mathrm{ab} \\
10.5 \mathrm{a} \\
9.1 \mathrm{c} \\
9.6 \mathrm{bc} \\
9.8\end{array}$ & $\begin{array}{r}55 \mathrm{a} \\
46 \mathrm{a} \\
5 \mathrm{~b} \\
44 \mathrm{a} \\
38\end{array}$ \\
\hline $\begin{array}{l}\text { Sugar Baby } \\
\text { Baby Fun } \\
\text { Minilee } \\
\text { Mickylee } \\
\text { Avg. }\end{array}$ & $\begin{array}{l}3.0 \mathrm{a} \\
2.6 \mathrm{a} \\
2.8 \mathrm{a} \\
2.6 \mathrm{a} \\
2.8\end{array}$ & $\begin{array}{l}27.0 \mathrm{~b} \\
28.3 \mathrm{~b} \\
30.9 \mathrm{a} \\
31.4 \mathrm{a} \\
29.4\end{array}$ & $\begin{array}{c}\text { Stored at } 200 \\
8.0 \mathrm{c} \\
8.9 \mathrm{c} \\
15.1 \mathrm{~b} \\
22.2 \mathrm{a} \\
13.6\end{array}$ & $\begin{array}{l}10.2 \mathrm{a} \\
8.4 \mathrm{a} \\
8.0 \mathrm{a} \\
9.1 \mathrm{a} \\
8.9\end{array}$ & $\begin{array}{r}9.5 \mathrm{a} \\
10.0 \mathrm{a} \\
9.4 \mathrm{a} \\
8.8 \mathrm{a} \\
9.4\end{array}$ & $\begin{array}{l}26 \mathrm{a} \\
19 \mathrm{a} \\
9 \mathrm{~b} \\
17 \mathrm{ab} \\
18\end{array}$ \\
\hline
\end{tabular}

${ }^{\mathrm{z}}$ All storage rooms maintained at $\pm 0.5 \mathrm{C}$ and $90 \%$ to $95 \% \mathrm{RH}$ in 5,10 , and $15 \mathrm{C}$ rooms and $70 \% \mathrm{RH}$ in 20C room.

${ }^{\mathrm{y}}$ Mean separation in columns (within a given storage temperature) by Duncan's multiple range test, $P=0.05$.

${ }^{\mathrm{x}}$ Ripeness: 1 = unripe, 2 = ripe, $3=$ overripe.

${ }^{\mathrm{w}}$ After storage for 4 weeks plus 4 days at $20 \mathrm{C}$. 
marketable fruit and $1 \mathrm{C}$ in the lowest. At 1 and $7 \mathrm{C}$ storage, CI was severe and decay originated at the sites of $\mathrm{Cl}$ during the additional week of storage at $21 \mathrm{C}$.

In the 1988 tests at Orlando, 'Baby Fun' fruit were more susceptible to $\mathrm{Cl}$ than either 'Mickylee' or 'Minilee' fruit during storage for 3 weeks at $1 \mathrm{C}$ (with or without conditioning at 26C for 3 days), plus 1 week at 21C (Table 3). Prestorage conditioning reduced the incidence and severity of CI. 'Mickylee' and 'Minilee' fruit were firmer than 'Baby Fun' fruit during storage, and firmness was not affected by increased storage temperature. TSS values were higher for 'Mickylee' than for 'Baby Fun' or 'Minilee.' The stems of 'Minilee' fruit had better appearance (absence of mold or decay) than those of either 'Baby Fun' or 'Mickylee' fruit. Fruit stored at 21C and at 1C with conditioning had more sound stems than fruit stored at 1 , 7, or 13C. 'Baby Fun' fruit were overripe and had more decay than 'Mickylee' or 'Minilee fruit during storage. The incidence of overripe fruit was the lowest for storage at $1 \mathrm{C}$, with or without conditioning, and highest for storage at $21 \mathrm{C}$. The incidence of decay was highest in fruit stored at $1 \mathrm{C}$. Storage at $1 \mathrm{C}$ with conditioning resulted in the highest amount of marketable fruit, and storage at $1 \mathrm{C}$ without conditioning in the lowest (Table 3). The humidity level during conditioning $(90 \%$ or $60 \% \mathrm{RH})$ did not affect any of the quality factors studied. Prestorage conditioning reduced the severity of CI with reduced incidence of decay and maintained a desirable stem condition.

The ripeness rating in the test at Gainesville for all cultivars tended to increase with increased storage temperatures during 4 weeks of storage at $5,10,15$, or $20 \mathrm{C}$ (Table 4). There were no differences among cultivars except for storage at $5 \mathrm{C}$. The initial ripeness ratings indicated that the fruit generally were harvested somewhat before being fully ripe. 'Mickylee' generally had the deepest red flesh, as indicated by the higher Hunter ' $a$ ' values, while 'Sugar Baby' had the lowest after storage. Firmness of the flesh was quite variable after storage, but 'Mickylee' fruit tended to be firmer than the other three cultivars. Rind thickness tended to decrease with increasing storage temperatures. Decay tended to be lower at $20 \mathrm{C}$ than at 10 or $15 \mathrm{C}$ storage and equal to that at 5C. 'Minilee' fruit had the lowest amount of decay compared to other cultivars at 10C and above. Most decay was limited to the stem end of the fruit, indicating that decay was from infection through the stem.

\section{Discussion}

Small watermelon cultivars respond similarly to large-fruited types during storage. 'Mickylee' and 'Minilee' responded very well to long-term storage. They maintained crispness, firmness, and TSS content. 'Minilee' fruit were less susceptible to CI and had less decay than the other cultivars tested. Subjecting small watermelons to storage at $\leq 7 \mathrm{C}$ for more than 1 week induced $\mathrm{CI}$ and led to decay after subsequent holding at room temper- ature. Conditioning (3 days at 26C) of small watermelons reduced the incidence and severity of CI and increased the percentage of marketable fruit for storage at $1 \mathrm{C}$, which is similar to the findings of Picha (1986). Conditioning not only reduced CI, but increased the percentage of sound stems. The high temperature of conditioning before cold storage tended to dry out the stems, which, presumably, reduced infection from the stem end of the fruit. Film-wrapping of melons caused excessive decay originating at the stem end, presumably because of the high relative humidity inside the wrapping (unpublished data). Data from a related test in Gainesville showed that artificially drying stems resulted in less decay than dipping fruit in SOPPtreated water.

Some shippers of small watermelons from Central America are using shipping temperatures $<7 \mathrm{C}$ without $\mathrm{CI}$; however, transit times are $<1$ week. Perhaps some inadvertent conditioning of fruit also occurs after harvest and before shipment, when time between harvest and shipment is 2 to 4 days (M. Harris, personal communication).

In our studies, long-term storage at $20 \mathrm{C}$ produced the highest percentage of marketable fruit and, generally, the lowest percentage of decayed fruit. However, fruit from long-term storage at 20C also had the lowest amount of TSS. The fruit flesh was also not as crisp as at lower storage temperatures. Therefore, 10 to $15 \mathrm{C}$ was in the best range for long-term storage for nonconditioned small watermelons. For 'Mickylee' and 'Minilee,' storage at $1 \mathrm{C}$ with conditioning at $26 \mathrm{C}$ for 3 days would be acceptable for long-term storage. These data agree with the recommendations of Hardenburg et al. (1986) and Dow et al. (1977) for large-type watermelons. Prestorage conditioning at ambient temperatures before storage at $1 \mathrm{C}$ should enhance longevity of watermelon during storage.

\section{Literature Cited}

Chisholm, D.N. and D.H. Picha. 1986. Effect of storage on sugar and organic acid contents of watermelons. HortScience 21:1031- 1033.

Crall, J.M. 1986. 'Minilee' and 'Mickylee,' two icebox-type watermelon cultivars with excellent fruit quality and resistance to both anthracnose and fusarium wilt. Univ. of Fla. Cir. S-336.

Dow, A.T., R.H. Segall, D.L. Hopkins, and G.W. Elmstrom. 1979. Effects of storage temperature and field fungicide treatments on decay of Florida watermelons. Proc. Fla. State Hort. Soc. 91:149150.

Hardenburg, R.E., A.E. Watada, and C.Y. Wang. 1986. The commercial storage of fruits, vegetables, and florist and nursery stocks. USDA Agr. Hdbk. 66.

Leupschen, N.S. 1961. The development of Mycosphaerella black rot and Pellicularia rolfsii rot of watermelons at various temperatures. Plant Dis. Rptr. 45:557-559.

Picha, D.H. 1986. Postharvest fruit conditioning reduces chilling injury in watermelons. HortScience 21(6):1407-1409.

Showalter, R.K. 1960. Watermelon color as affected by maturity and storage. Proc. Fla. State Hort. Soc. 73:289-293. 